\begin{tabular}{|c|c|}
\hline & International Journal of Current Research in \\
Biosciences and Plant Biology \\
BXCELENT \\
PUBLISHERS
\end{tabular}

\title{
Integrated Agricultural System Study on Crops: Intercropping of Corn - Peanut and Beef Cattle Fattening
}

\section{Syamsul Bahri ${ }^{*}$, Asmuddin Natsir ${ }^{2}$, Nurani Sirajuddin ${ }^{2}$ and Syamsuddin Hasan ${ }^{2}$}

\author{
${ }^{1}$ Graduate Program of Hasanuddin University, Makassar, Indonesia \\ 1Department of Animal Husbandry, Faculty of Agriculture, State University of Gorontalo, Indonesia \\ ${ }^{2}$ Faculty of Animal Husbandry, Hasanuddin University, Makassar, Indonesia
}

*Corresponding author.

\begin{tabular}{|c|c|}
\hline Article Info & ABSTRACT \\
\hline $\begin{array}{l}\text { Date of Publication: } \\
06 \text { April } 2018\end{array}$ & \multirow{3}{*}{$\begin{array}{l}\text { The objectives of the study were to investigate the effect of combination of compost } \\
\text { and urea fertilizer, the level of leaf defoliation under cobs and their interaction with } \\
\text { corn and peanut production, to examine the effect of combining corn waste and peanut } \\
\text { waste on feed consumption, weight gain and beef cattle ration conversion and } \\
\text { feasibility of integrated farming system between beef cattle with corn and peanut } \\
\text { crops. This study was conducted for } 8 \text { months using Separate Plot Design with a leaf } \\
\text { defoliation treatment under the cob as the main plot and the combination of fertilizer } \\
\text { as a plot for the first stage and Randomized Design complete with ration mixture } \\
\text { treatment of corn and peanut waste for the second phase trial. The results showed that } \\
\text { the combination of fertilization yielded relatively equal production of maize and } \\
\text { different peanuts while defoliation of } 50 \% \text { of the leaves under the cob and its } \\
\text { interaction could increase the production of corn and peanuts, the combination of } \\
\text { maize and peanut ( } 50 \%: 50 \% \text { ) showed a better response to feed intake, weight gain and } \\
\text { beef cattle rations conversion and was a viable farming commodity cultivated in an } \\
\text { integrated farming system. }\end{array}$} \\
\hline Keywords & \\
\hline $\begin{array}{l}\text { Beef cattle } \\
\text { Compost } \\
\text { Integrated agricult } \\
\text { Intercropping } \\
\text { Plant waste silage }\end{array}$ & \\
\hline
\end{tabular}

\section{Introduction}

Indonesia's population from year to year continues to increase. The logical consequence is that the level of demand for vegetable and animal foods is growing, on the other hand in densely populated areas, the productive lands that are our foundation for increasing the production of food and non-food commodities are shrinking. The rate of depreciation of agricultural land in Indonesia is accelerating due to land fragmentation or depreciation of agricultural land ownership as a system impact for inheritance and land conversion. The transfer of land from agricultural land to non-agricultural land occurs everywhere. This situation resulted in the increasingly pressing agricultural activities toward 
marginal lands, especially dry land that has complex problems.

Judging from the technology developed today, it tends to lead to two opposite poles, namely: agriculture with high external input (green revolution) and agriculture with low external input (Reijntjes et al., 1999). Both of these technologies are developed in the end can have a very significant impact on the environment of farming. In addition, state support (power), international agencies and market support tend to favor monoculture, homogeneous, uniform farming systems with the use of new varieties that are responsive to fertilizers and pesticides (Sukara, 2003) but have significantly contributed to the destruction of nature and stoning agricultural systems that have been developed based on the wisdom of farming communities. The existing phenomenon provides an illustration that there should be a serious and intelligent effort to develop agriculture that is not only economically oriented but also considers the social feasibility and environmental sustainability. One of them is to use all the existing agricultural potential of both food crops and farms in a system integrated with technology both in the utilization of farm waste as organic fertilizer plants and utilization of agricultural waste as animal feed.

The potential of livestock as a provider of organic fertilizer is maximized through the processing of feces and urine as compost. Provision of compost fertilizer by reducing the use of artificial fertilizers to measure the effectiveness of its use has not been widely reported. Based on the above considerations, the first phase of the research was conducted to assess the effectiveness of compost fertilizer in corn and peanut crops with the intercropping pattern along with the study of corn leaf defoliation under the cob as a synergy effort between corn and peanut and shade minimization efforts. Potential of food crop agriculture, especially as food supplier and source of ruminants, the feed can be done by processing of food crop waste as animal feed in the form of silence based on local resources. This effort is done in order to anticipate the availability of feed that is still a constraint to the development of ruminant livestock in Indonesia. The more narrow forage cultivation of forage because it is converted into the residential and industrial area also become one of the causes. Consequently, the quality and price of feed become fluctuated, further affecting the livestock products. So we need a feed preparation technology that not only holds the store but also contains nutrients in accordance with the needs of livestock. Utilization of raw material silage combination of corn and peanut byproducts with a certain ratio has not been applied by many farmers in the field. Based on the above considerations, a second phase study was conducted to examine the effect of silage combinations of corn and peanut byproducts on consumption, body weight gain and feed conversion of beef cattle. On the basis of the above-mentioned thinking, we conducted a study of the integrated farming system through the use of compost and silage waste food crops.

\section{Materials and methods}

The first stage is the utilization stage of cow dung, using Separate Plot Design (RPT) with the defoliation treatment of the leaf below the cob as the main plot and the combination of dosage of urea fertilizer and compost as the subplot. The treatment under study is as follows:

1. Leaf defoliation below the casks as mainp (main plot)

$$
\begin{aligned}
& \mathrm{d} 0=\text { Without defoliation (control) } \\
& \mathrm{d} 1=\text { Defoliation } 50 \% \\
& \mathrm{~d} 2=\text { Defoliation } 100 \%
\end{aligned}
$$

2. Combination of urea fertilizer dosage and compost as subplot (sub plot)

$$
\begin{aligned}
& \mathrm{p} 0=250 \mathrm{~kg} \text { Urea } / \mathrm{ha}+3 \text { tons of compost } / \text { ha } \\
& \mathrm{p} 1=230 \mathrm{~kg} \text { Urea } / \mathrm{ha}+6 \text { tons of compost } / \text { ha } \\
& \mathrm{p} 2=210 \mathrm{~kg} \text { Urea } / \mathrm{ha}+9 \text { tons of compost } / \text { ha } \\
& \mathrm{p} 3=190 \mathrm{~kg} \text { Urea } / \text { ha }+12 \text { tons of compost } / \text { ha }
\end{aligned}
$$

Each combination is repeated three times so that the total number is 36 plot experiments. Data were analyzed by using variance analysis and analysis of 
continuation test of the smallest difference (BNT).The second stage is the utilization of corn waste and peanut waste in the form of silage and commercial concentrate of PT. The Brilliant Living order tested in 12 cows with 200-250 kg weight using complete randomized design (RAL) consisting of four treatments and three replications.

The four kinds of ration treatment are:

$$
\begin{aligned}
\mathrm{R} 0= & \text { Silage corn }+ \text { Combo } \\
\mathrm{R} 1= & \text { Silage combination LJ and LKT }(60 \%+40 \%) \\
& + \text { Concentrate } \\
\mathrm{R} 2= & \text { Silage combination } \mathrm{LJ} \text { and LKT }(50 \%+50 \%) \\
& + \text { Concentrate }
\end{aligned}
$$

$\begin{aligned} \mathrm{R} 3= & \text { Silage combination LJ and LKT }(40 \%+60 \%) \\ & + \text { Concentrate }\end{aligned}$

\section{Results and discussion}

\section{Corn waste production}

Fig. 1 shows that treatment without defoliation with 6 tons of compost $\mathrm{ha}^{-1}(\mathrm{~d} 0 \mathrm{p} 2)$ tends to produce higher average yield of corn waste per hectare (9.49 tons $\mathrm{ha}^{-1}$ ), while $50 \%$ defoliation treatment in corn leaves below cobs with 12 tons of $\mathrm{ha}^{-1}$ compost (d1p4) tended to produce a lower average yield of maize waste per hectare $\left(7.26\right.$ tons $\left.\mathrm{ha}^{-1}\right)$ than other treatments.

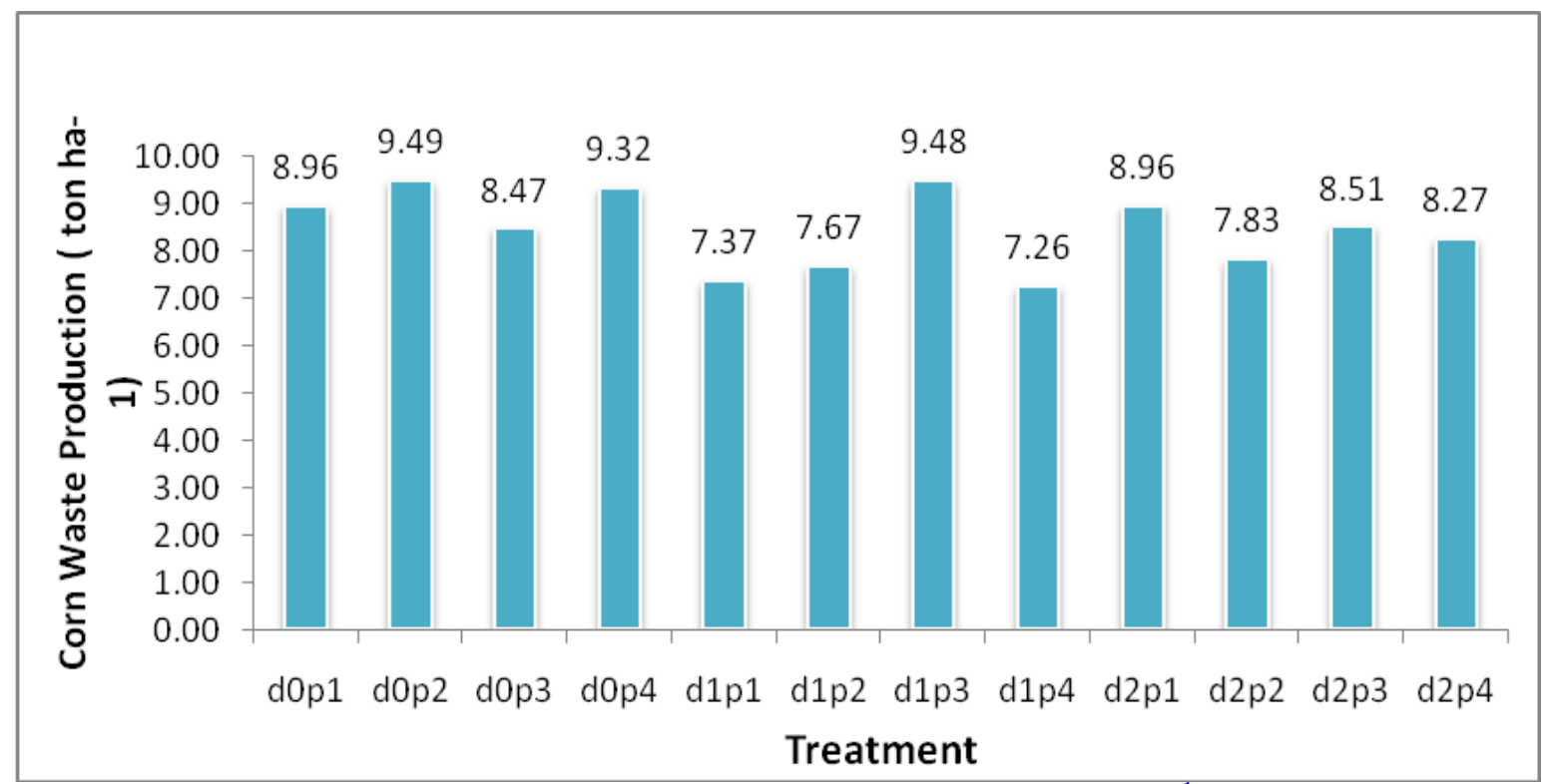

Fig. 1: Average production of fresh corn waste $\left(\right.$ ton $\left.\mathrm{ha}^{-1}\right)$.

The existence of defoliation as an act of eliminating or reducing the leaves of less productive is one alternative to spur photosynthesis process which in turn will increase the production of planting, but decrease the production of maize waste. According to Nasaruddin (2002), the defoliation of leaves that are not effective in photosynthesis is intended to reduce internal competitors between the parts of the plants that become the users of assimilates, in addition to other purposes such as leaves can be used for ruminants feed or prevent the accumulation of plants so easy occupied nesting various pests and diseases.

\section{Production of peanut waste}

Table 1 shows that the interaction between $50 \%$ defoliation in corn leaves under cobs with 3 tons of compost $\mathrm{ha}^{-1}(\mathrm{~d} 1 \mathrm{p} 1)$ yields the highest average peanut per hectare production (24.08 ton ha ${ }^{-1}$ ) but not significantly different other treatment. The percentage of leaf defoliation under the cob has no effect on the observation component of maize waste production and peanut waste production. While the interaction of the combination of fertilizer with defoliation percentage gives effect to peanut waste production. 
Table 1. Average fresh production of peanut wastes $\left(\right.$ ton $\left.\mathrm{ha}^{-1}\right)$.

\begin{tabular}{|c|c|c|c|c|}
\hline \multirow{2}{*}{ Defoliation } & \multicolumn{4}{|c|}{ Fertilization level } \\
\hline & $p_{1}$ & $\mathbf{p}_{2}$ & $\mathbf{p}_{3}$ & $\mathbf{p}_{4}$ \\
\hline $\mathrm{d}_{0}$ & $20.90^{\text {abcd }}$ & $19.73^{\mathrm{bcd}}$ & $19.61^{\mathrm{bcd}}$ & $22.51^{\mathrm{ab}}$ \\
\hline $\mathrm{d}_{1}$ & $24.08^{\mathrm{a}}$ & $21.91^{\mathrm{abcd}}$ & $20.25^{\text {bcd }}$ & $19.74^{\text {bcd }}$ \\
\hline $\mathrm{d}_{2}$ & $17.77^{\mathrm{d}}$ & $18.72^{\text {cd }}$ & $21.58^{\mathrm{abc}}$ & $21.56^{\mathrm{abc}}$ \\
\hline
\end{tabular}

Description: The numbers followed by the same letter mean not significantly different at the test level BNT=0.05.

Defoliation of $50 \%$ and 3 tons of compost ha-1 allows the growth of vegetative soil cultivated plants so that the habit of the plant becomes thick, eventually, vegetative organs such as stems and leaves produced more which causes the average production of plant waste generated also more. This is assumed by the combination of fertilizer and $50 \%$ defoliation is able to spur the rapid growth of vegetative plants peanuts, especially leaf and its completeness for photosynthesis. Linga (1991), suggests that nitrogen plays an important role in terms of leaf green formation which is very useful in the process of photosynthesis. Another function is to form proteins, fats, and various organic compounds. The capacity of photosynthesis increases with increasing number of leaves in peanut plants (Salisbury and Ross, 1991).

\section{Feed consumption}

Table 2 shows that the combined silage treatment of corn and peanut waste (50\%: 50\%) (r2) resulted in the highest average consumption of dry matter $(6.81 \mathrm{~kg} / \mathrm{head} /$ day $)$ and significantly different from other treatments. The high consumption of ration (r2) of combination silage of corn and peanut waste in the ratio of $50 \%: 50 \%$ is suspected because of the high level of palatability of livestock due to the quality of fermentation (physical and chemical) silage and nutritional quality are also good, especially the content of substances -the nutritional protein as in the proximate analysis of treatment rations.

Table 2. Average consumption of dry matter feed (kg/head/day).

\begin{tabular}{lll}
\hline Treatment & Average & BNT $_{\mathbf{0 . 0 5}}$ \\
\hline $\mathrm{r}_{0}$ & $4,90^{\mathrm{d}}$ & \\
$\mathrm{r}_{1}$ & $6.50^{\mathrm{b}}$ & \\
$\mathrm{r}_{2}$ & $6.81^{\mathrm{a}}$ & 0.1401 \\
$\mathrm{r}_{3}$ & $5.76^{\mathrm{c}}$ & \\
\hline
\end{tabular}

Description: The numbers followed by the same letter mean not significantly different at the test level BNT $=0.05$.

The average consumption of dry ration material in Balinese cattle with control ration, combined silage of corn and peanut syrup with various comparisons (60\%: 40\%), (50\%: 50\%) and (40\%: $60 \%$ ) were $4.90 \mathrm{~kg} /$ head / day, $6.50 \mathrm{~kg} / \mathrm{head} /$ day, $6.81 \mathrm{~kg} / \mathrm{head} /$ day and $5.76 \mathrm{~kg} / \mathrm{head} / \mathrm{day}$. The dry matter consumption data on the r2 treatment (50\%: 50\%) was able to exceed the consumption of control treatment feed (r0), r1 (60\%: 40\%) and r3 (40\%: 60\%) where the control treatment showed the lowest consumption. Thus the treatment of silage combination of corn and peanut (r2) waste in Bali cattle had higher palatability level than treatment of $\mathrm{r} 0, \mathrm{r} 1$, and $\mathrm{r} 3$. The level of feed consumption of a broiler is influenced by various complex factors, namely the animals themselves, the food is given and the environment in which the animals are kept and the factors that almost all of them are caused by the fermentation process. Substances that are negatively correlated with consumption levels include NH3 concentrations, acetate, total VFA while the positively correlated with consumption rate is lactic acid. Besides silage dry matter and silage particle size also influence either directly or indirectly to consumption level (Parakkasi, 1999). 


\section{Weight gain}

Table 3 shows that the combined silage treatment of corn and peanut waste $(50 \%$ : 50\%) $(\mathrm{r} 2)$ resulted in the highest average weight gain $(0.80 \mathrm{~kg} / \mathrm{head} /$ day $)$ and the silage of maize $(\mathrm{r} 0)$ yielded flat the lowest weight gain $(0.52 \mathrm{~kg} / \mathrm{head} /$ day $)$ and significantly different from other treatments. The increase in body weight can be due to the protein and energy requirements of the ration consumed has sufficient daily protein and beef cattle for live basic compared to the control treatment and other combination treatment.

Table 3. Average weight gain ( $\mathrm{kg} /$ head / day).

\begin{tabular}{lll}
\hline Treatment & Average & BNT $_{\mathbf{0 . 0 5}}$ \\
\hline $\mathrm{r}_{0}$ & $0.51^{\mathrm{c}}$ & \\
$\mathrm{r}_{1}$ & $0.72^{\mathrm{b}}$ & \\
$\mathrm{r}_{2}$ & $0.80^{\mathrm{a}}$ & 0.0378 \\
$\mathrm{r}_{3}$ & $0.64^{\mathrm{b}}$ & \\
\hline
\end{tabular}

Description: The numbers followed by the same letter mean not significantly different at the test level $\mathrm{BNT}=0.05$.

The increase in livestock weight can reflect the extent of the benefits of feed given to livestock. The increase of body weight in the treatment of silage combination of corn and peanut waste can be caused by protein and energy requirement from the ration consumed has sufficient daily requirement of protein and energy of beef cattle for basic life compared with control treatment and other combination treatment. In addition, increased weight gain is also suspected because the content of nutritional substances is higher than the control treatment so that protein nutrients contained in the combination treatment rations corn and peanuts can be digested and absorbed by the digestive tract in large amounts become heavy body compared with those wasted through feces and urine. It's just that the use of peanut wastes is limited to $50 \%$ percentage, although the peat treatment percentage of peanuts $60 \%$ has nutritional value better than other treatments. Percentage of peanut waste more than $50 \%$ in the field, seen cows that consume the feed feces become more dilute (diarrhea) and tend to reduce consumption. This is consistent with that of Saun (1991), that cattle can be fed from legumes (beans) between $30-35 \%$ of the feed, because if given with the composition more than that the livestock will be excess $\mathrm{Ca}$ (calcium) and lack of other substances so better combined with corn waste.

\section{Conclusion}

Based on the results, analysis, and discussion of research conducted, it can be concluded as follows:

1. The combination of urea and compost fertilizers produces uniform corn and peanut waste production and there is an interaction between the combination of fertilization and the level of leaf defoliation below the cob in increasing the production of corn and peanut waste.

2. The combined ration of corn waste and peanut waste (50\%: $50 \%)$ showed a better response than other rations on ration consumption, weight gain and feed conversion, with a peanut use limit of up to $50 \%$ when combined with waste corn.

3. Application of integrated agriculture through the technology of utilization of compost fertilizer and silage of food crop waste is feasible to be developed at farmers in order to support food security.

\section{Conflict of interest statement}

Authors declare that they have no conflict of interest.

\section{References}

Amali, N., Rohaeni, E. S., Darmawan, A., Sumanto, Subhan, A., Pagiyanto, Nurarwaliyah, S., 2003. An adaptive assessment of beef cattle in crop farming system in the dry land of South Kalimantan. BPTP South Kalimantan. Banjarbaru.

Anwar, K., 2003. Management and utilization of livestock manure in increasing the production of food crops. Paper of Application of Agricultural 
Technology Package at BPTP Kalsel on 8 - 9 December 2003.

AOAC [Association of Official Analytical Chemist], 1999. Official Methods of Analysis. Ed 16th. Washington: AOAC International.

Gaspersz, V., 1999. Experimental Design Methods for Agricultural Sciences, Engineering Sciences, Biology. CV. Amico, Bandung.

Hashemi-Dezfouli, A., Herbert, S.J., 1992. Intensifying plant density responses of corn with artificial shade. Agron. J. 84, 547-551.

Kadekoh, I., 2003. Land use efficiency, calorie equivalent value, and protein at various times of maize defoliation and distance of peanut planting in intercropping system in different season. J. Agricult. 14, 99-105.

Kadekoh, I., 2005. Sustainable agriculture development of dry land with intercropping pattern and aisle cultivation. Scientific Inauguration of Professor of Tadulako University. The University of Tadulako. Hammer.

Najib, M., Rohaeni, E. S., Tarmudji, 1997. The role of cattle in crop farming system in a dry land. Proceedings of National Seminar on Livestock and Veterinary. Bogor. 18-19 November 1997. Volume II. Wageningen Agric. Univ., Wageningen, Netherland. pp.759-766.
Pasaribu, T.B., Tangendjaja, Vienna, E., 1995. Silage sweet corn skin as sheep feed. Inside: Proceedings of National Seminar on Livestock Science and Technology. pp.170-175.

Perry, T.W., Cullison, A.E., Lowrey, R.S., 2003. Feeds and Feeding. 6th Edn. Prentice Hall Inc., New Jersey.

Rasjid, S., 2005. The Miracle of Ruminants. Scientific Inauguration of Professors. Presented at Hasanuddin University's Extraordinary Senate Open Meeting on May 7, 2005. Hasanuddin University Press.

Reijntjes, C., Haverkart, B., Waters, B., 1999. Agriculture of the Future. Introduction to Sustainable Agriculture with Low External Input. Kanisius, Yogyakarta.

Rohaeni, E. S., Amali, N., Subhan, A., 2006. Fermented Maize Jenggel as Alternative Feed for Cattle in the Dry Season. Inside: Proceedings of National Workshop on Development Network of Corn-Cow Integration System; Pontianak, 9-10 August 2006. Puslitbangnak. Agriculture Department. pp.193196.

Sutanto, R., 2002. Organic Farming towards Alternative and Sustainable Agriculture. Kanisius, Yogyakarta.

\section{How to cite this article:}

Bahri, S., Natsir, A., Sirajuddin, N., Hasan, S., 2018. Integrated agricultural system study on crops: Intercropping of corn - peanut and beef cattle fattening. Int. J. Curr. Res. Biosci. Plant Biol. 5(4), 24-29. doi: https://doi.org/10.20546/ijcrbp.2018.504.004 